\title{
The use of LCA in the water industry and the case for an environmental performance indicator
}

\author{
E Friedrich $^{1 *}$, S Pillay ${ }^{2}$ and CA Buckley ${ }^{2}$ \\ ${ }^{1}$ School of Civil Engineering, Surveying and Construction, University of KwaZulu-Natal, South Africa \\ ${ }^{2}$ Pollution Research Group, University of KwaZulu-Natal, South Africa
}

\begin{abstract}
This paper reviews the use of environmental life-cycle assessments (LCAs) in the water industry internationally and locally. An LCA conducted on the water supply, treatment and recycling in the eThekwini Municipality is used for demonstrative purposes. Many of the LCAs reviewed, including the case study, have demonstrated that in the treatment of water (potable water and wastewater) most of the environmental impacts are traced back to the use of energy - in most cases the use of electricity. Therefore, it is proposed that for South Africa the electricity consumption of different water treatment processes can be used as an environmental indicator of impacts. Advantages and limitations in using electricity consumption as an indicator are also presented.
\end{abstract}

Keywords: life-cycle assessment, water treatment processes, energy consumption

\section{Introduction to the use of LCA in the water industry}

Water is an important resource for South Africa and much effort has been put into the sustainable provision of water in this country. A series of laws and by-laws, most notably the National Water Act (Act 36 of 1998) reflects this. However, all efforts are targeting the ecological Reserve, the sustainability in obtaining the water from the environment and the effects of discharges to the rivers. There is less work done on the sustainability of the processes involved in producing potable water from raw water and those used in the treatment of wastewater. This paper aims to address this gap and it presents how one environmental tool, namely the life- cycle assessment (LCA) is used in the water industry. In the $1^{\text {st }}$ part of the paper the concept of LCA is introduced. In the $2^{\text {nd }}$ part it is shown how LCAs are used in the water industry internationally and locally and what results have been obtained. In the $3^{\text {rd }}$ part of the paper an indicator for measuring the environmental performance of water treatment processes in South Africa is proposed.

In the South African Bureau of Standards (SABS) and the International Organisation for Standardisation (ISO) 14040 standard (1997), the definition of LCA is given as follows: ' $L C A$ is a technique for assessing the environmental aspects and potential impacts associated with a product, by:

- Compiling an inventory of relevant inputs and outputs of a system,

- Evaluating the potential impacts associated with those inputs and outputs,

- Interpreting the results of the inventory analysis and impact assessment phases in relation to the objectives of the study.

LCA studies the environmental aspects and potential impacts

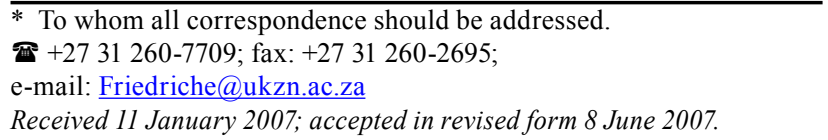

throughout a product's life (i.e. cradle-to-grave) from raw material acquisition through production, use and disposal. The general categories of environmental impacts needing consideration include resource use, human health and ecological consequences.'

Table 1 (next page) presents a brief overview of these three sections plus the preliminary goal and scope definition phase. It also shows how each phase is typically addressed in the water sector.

\section{A review of the different LCA studies in the water industry}

The number of LCA applications and the number of users of LCAs in the water industry increased dramatically in the 1990s and 2000s. In the 1990s LCA was employed in a few studies mainly in Europe (UK, Sweden, Switzerland and the Netherlands). However, over the past years more studies have been performed in the developed world but also in developing countries like South Africa, Mexico and countries in south-east Asia. The tool is applied at different levels as Jensen et al. (1997) noted. These levels are the conceptual LCA or life cycle thinking, the simplified (or streamlined LCA) and the academic, detailed LCA. In the water industry LCA studies have been applied at a strategic and/or regional level, at project and process level and at a very specific (e.g. the choice of different piping materials) level. The studies reviewed in this paper are a combination of simplified and detailed LCAs, at all applications levels and a summary is provided in Table 2 .

\section{LCA applications for wastewater treatment plants}

Emmerson et al. (1995) performed one of the first LCA studies in the water industry and they used the LCA tool to evaluate the environmental impacts of small-scale sewage treatment works. Three different sewage works with different process options were analysed to identify and quantify material use, energy use and environmental releases during the life cycle of the physical 


\begin{tabular}{|c|c|c|}
\hline \multicolumn{3}{|c|}{$\begin{array}{c}\text { TABLE } 1 \\
\text { Overview of the LCA methodology }\end{array}$} \\
\hline $\begin{array}{l}\text { Phase of } \\
\text { an LCA }\end{array}$ & Definition/Description & Examples in the water sector \\
\hline $\begin{array}{l}\text { 1. Goal and } \\
\text { scope defini- } \\
\text { tion }\end{array}$ & $\begin{array}{l}\text { The purpose of the study is specifically stated and the } \\
\text { boundaries of the system to be analysed are appropri- } \\
\text { ately identified. Particularly important in this phase is } \\
\text { the definition of a functional unit. }\end{array}$ & $\begin{array}{l}\text { In the water sector the default functional unit is metric such as } 1 \mathrm{k} \ell \text { or } \\
1 \mathrm{M} \ell \text { of water at the quality specified for that particular process. For exam- } \\
\text { ple, for the production of potable water in the eThekwini Municipality the } \\
\text { functional unit is } 1 \mathrm{k} \ell \text { of treated water to the quality specified by Umgeni } \\
\text { Water and the eThekwini Municipality as necessary for potable water. }\end{array}$ \\
\hline $\begin{array}{l}\text { 2. Inventory } \\
\text { analysis }\end{array}$ & $\begin{array}{l}\text { All the inputs and outputs from all the processes } \\
\text { included in the system are related to the functional } \\
\text { unit and together they form the inventory list for that } \\
\text { particular system. Inventory lists are long tables, } \\
\text { which cannot be interpreted as such and they are not } \\
\text { presented in most of the LCA studies reviewed. }\end{array}$ & $\begin{array}{l}\text { Local data (infrastructure, chemicals and energy usage) are collected for } \\
\text { individual waterworks (potable and wastewater) and processes. All the } \\
\text { initial data (first-degree data) are usually presented in the reviewed stud- } \\
\text { ies (e.g. amount of chemicals and energy used per kl). The underlying } \\
\text { data or second (or third) degree data (e.g. production of those chemicals, } \\
\text { energy and infrastructure) used is obtained by collecting it directly (e.g. } \\
\text { the production of sodium hypochlorite, cement, lime, oxygen, etc.) and } \\
\text { from different commercial and academic LCA databases (e.g. production } \\
\text { of electricity, chlorine, different plastics, etc.). } \\
\text { For example, the inventory list for the production of potable water at Wig- } \\
\text { gins Waterworks in the eThekwini Municipality has } 268 \text { entries (Frie- } \\
\text { drich et al., 2006). One example of such an entry is the sulphur dioxide } \\
\text { released to air (due to the combustion of coal used to produce electricity, } \\
\text { which is used for pumping). This inventory list is the input to the next } \\
\text { phase of the LCA, which is the impact assessment. }\end{array}$ \\
\hline $\begin{array}{l}\text { 3. Impact } \\
\text { assessment }\end{array}$ & $\begin{array}{l}\text { The significance of the potential impacts resulting } \\
\text { from the inputs and outputs of the system, as presented } \\
\text { in the inventory, are assessed in this phase. Each entry } \\
\text { of the inventory will be translated into contributions to } \\
\text { environmental problems and human health. Elements } \\
\text { mandatory for this phase are: } \\
\text { - Selection of impact categories, category indicators } \\
\text { and characterisation models (also referred to as } \\
\text { category definition); } \\
\text { - Assignments of inventory results to the impact cat- } \\
\text { egory (classification) and } \\
\text { - Calculation of category indicator results (charac- } \\
\text { terisation). } \\
\text { Optional elements are normalisation (calculation of } \\
\text { the magnitude of category indicator results relative to } \\
\text { reference information), grouping, weighting and data } \\
\text { quality analysis. } \\
\text { All the scores from all the categories considered } \\
\text { make up the environmental profile of the system or } \\
\text { product studied. }\end{array}$ & 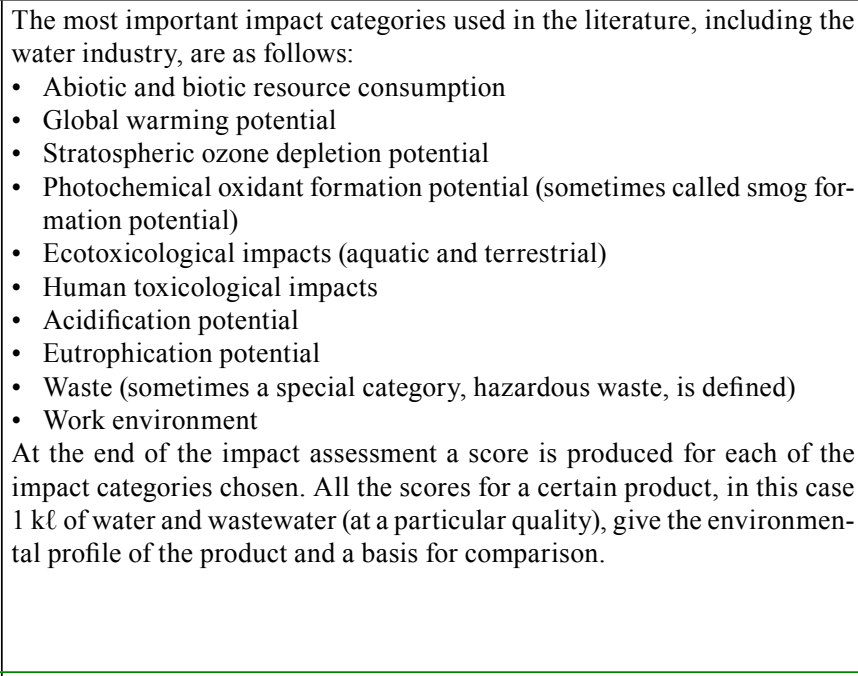 \\
\hline $\begin{array}{l}\text { 4. Interpre- } \\
\text { tation }\end{array}$ & $\begin{array}{l}\text { This phase aims to present a number of key issues, } \\
\text { which will be usable in a decision-making process, } \\
\text { based on the inventory and the impact assessment of } \\
\text { the system. Such key issues are usually opportunities } \\
\text { to reduce material and energy inputs and/or environ- } \\
\text { mental impacts in the life cycle of the product/activ- } \\
\text { ity/service. }\end{array}$ & $\begin{array}{l}\text { The key issues for the different LCAs in the water industry are presented } \\
\text { in the review of the different applications. } \\
\text { Sensitivity and uncertainty analyses are usually performed in order to } \\
\text { determine the sensitivity of the results (i.e. the scores calculated per } \\
1 \mathrm{k} \ell \text { of water or wastewater) to changes of input data. For the water sector } \\
\text { such changes could be changes in the amount of chemicals and energy } \\
\text { used per } 1 \mathrm{k} \ell \text { of water or wastewater. }\end{array}$ \\
\hline
\end{tabular}

assets (i.e. construction, operation and decommissioning). One of the most important issues emerging from this study is that energy use is an important contribution to the total environmental impact associated with small-scale sewage plants. Therefore, energy saving and improved efficiency is an important recommendation. Over a 15-year lifetime the biological filter plants were found to use on average $56 \%$ less energy than the activated-sludge plants and to produce $35 \%$ fewer airborne emissions. Therefore, the use of these plants has been encouraged for rural areas where land availability and the low toxicity of resulting solid wastes are not seen as problems.

Another LCA in the wastewater field was carried out by Tillman et al. (1998) in Sweden. This study investigated two different municipal wastewater systems: a very small system (servic- ing a population of 900) and a small to medium system (servicing 12600 people). Although this study goes into much detail, it is not possible to compare its results to other wastewater studies because the researchers chose to enlarge the system to include, for example, the production of fertiliser which is saved by the agricultural utilisation of the nitrogen removed from wastewater. The researchers came up with improvement scenarios for the existing systems. For the very small treatment plant, urine separation and the digestion of the remaining wastewater (both of which were to be reused in agriculture) scored best. For the small to medium plant the results were not so clear cut because this system was a net producer of energy and contributed to the district heating system. One should note that the geographical locality of the study is important for such energy calculations, 


\begin{tabular}{|c|c|}
\hline \multicolumn{2}{|c|}{$\begin{array}{c}\text { TABLE } 2 \\
\text { Literature studies included }\end{array}$} \\
\hline Level of application & Researchers/Reference \\
\hline 1. Strategic/regional & $\begin{array}{l}\text { Lundie and Peters (2000) } \\
\text { Tarantini and Ferri (2001) } \\
\text { Rihon et al. (2002) } \\
\text { Friedrich et al. (2006) }\end{array}$ \\
\hline 2. Project/process & $\begin{array}{l}\text { Emmerson et al. (1995) } \\
\text { Meijers et al. (1998) } \\
\text { Tillman et al. (1998) } \\
\text { Dennison et al. (1998) } \\
\text { Brydle and Skrypski-Mantele (2000) } \\
\text { Hwang and Hanaki (2000) } \\
\text { Zhang and Wilson (2000) } \\
\text { Vidal et al. (2000) } \\
\text { Friedrich (2001) } \\
\text { Danish EPA (2002) } \\
\text { Raluy et al. (2005) } \\
\text { Strokes and Horvath (2006) } \\
\text { Landu and Brent (2006) } \\
\end{array}$ \\
\hline 3. Material/specific & $\begin{array}{l}\text { Jeschar et al. (1995) } \\
\text { Forschungsinstitut für Chemie } \\
\text { und Umwelt (1996) } \\
\text { Dennison et al. (1999) }\end{array}$ \\
\hline
\end{tabular}

since in the southern hemisphere energy recovered for heating would be not necessarily desirable.

Zhang and Wilson (2000) performed an LCA for a large $\left(164000 \mathrm{~m}^{3} / \mathrm{d}\right)$ sewage treatment plant in south-east Asia. This study reinforced the results by Emmerson et al. (1995) pointing to energy as the main contributor to the environmental burdens of treating water. The results showed that nearly $70 \%$ of the energy consumption occurred during the operational phase. This is considered to be a good performance with units running below design estimates; however, improvement opportunities have been identified in order to increase energy efficiency even further. Large sewage treatment plants are more energy-efficient compared with small-scale ones. Per capita energy consumption for the plant investigated by Zhang and Wilson (2000) (serving a population of 800000 ) was about $25 \%$ of the small-scale plant investigated by Emmerson et al. (1995) (serving a population of $1000)$. Both plants used the activated sludge process but operate in different geographical zones resulting in different average temperatures. There was no information on the discharge standards.

The LCA tool was used by Vidal et al. (2002) to compare the environmental implications of performing structural changes to an activated sludge wastewater treatment plant. The aim of these structural changes was to reduce nitrogen concentrations in the effluent. Two different configurations were considered as modifications to the existing scenario and they performed LCAs on all three scenarios. Based on the results of these LCAs it was possible to single out the configuration (the oxidation ditch) which caused fewer environmental impacts and achieved acceptable nitrogen removal.

Another comparative LCA study was commissioned by the Danish EPA (2002) to look at the environmental consequences of treating wastewater resulting from the fisheries sector. Four technologies were studied: thermal flotation, chemical flotation, membrane filtration and biological treatment. The researchers looked at each technology individually and then considered combinations of two technologies. They concluded that thermal flotation has the highest environmental burdens. Using natural gas as source of energy, however, could lower these burdens. Membrane filtration had the second highest burdens, but the technology is relatively new in the fishing industry and there are many opportunities for increasing efficiency. Chemical flotation and biological cleaning scored best; however, mercury discharged and the production of ferro- chloride, both used for chemical flotation are seen as considerable problems. This study is interesting since it presents one of the few applications by industry for effluent treatment.

\section{LCA applications for water supply}

Raluy et al. (2005) used LCA to compare three commercial desalination technologies - reverse osmosis (RO), multi-effect desalination (MED) and multi-stage flash (MSF) used to supply potable water. In their results they single out the operational stage of all three technologies as having the highest environmental burdens. The construction and disposal phases are having negligible contributions when compared to the operational stage. For all three technologies energy used is the main contributor towards environmental burdens and the technology used to provide this energy is considered an important factor. Among the three technologies RO is having the lowest environmental burdens (one order of magnitude lower than the other two). The environmental performance of thermal desalination (MED and MSF) can be increased and become comparable with RO if combined with additional processes, which take advantage of the resultant residual heat.

Another LCA study for water supply was performed by Strokes and Horvath (2006). They used a hybrid LCA approach (which combines elements of a process-based and economic an input-output LCA) to compare three supply alternatives: importing, recycling and desalinating water a Northern and a Southern California water utility. According to the authors 'for the two case studies desalination had 2 to 5 times larger energy demand and caused 2 to 18 times more emissions than importation and recycling and the operation life-cycle phase created the most energy consumption with $56 \%$ to $90 \%$ for all sources and case studies. The authors concluded that recycling water was found to be more energy intensive in Northern than in Southern California and the results for importing water were similar' and for all alternatives in both case studies, the energy consumed by system operation dominated the results, but maintenance was found to be significant. Energy production was found to be the largest contributor in all water provision systems, followed by material production (Strokes and Horvath, 2005).

\section{Assessment of sludge disposal and reuse}

Dennison et al. (1998) published the preliminary results of an LCA study comparing the disposal of sludge at 15 wastewater treatment works under the management of Thames England and Wales Water Utilities Ltd. Nine of these works were disposing sludge by subsoil injection and for the other works the sludge was either transported and disposed directly to land by tanker or transported to larger works from where it is then disposed to land. Composting and digestion were also investigated. The results from this study indicate that environmental improvement can be achieved by de-watering the sludge at the wastewater works and saving transport. Taking into consideration the category of global warming alone, composting as opposed to digestion is preferred. 
Bridle and Skrypski-Mantele (2000) performed an LCA sludge study for the Water Corporation of Western Australia. The aim was to evaluate treatment/disposal options for sludge and five treatment options were assessed: anaerobic digestion, lime stabilisation, thermal drying of raw sludge, thermal drying of digested sludge and sludge conversion to oil (a new technology). Four major criteria for the environmental assessment of these options have been proposed and they differ somewhat from the classical criteria of standard LCAs. These criteria are: environmental/health protection, resource recovery, recovered vs. invested resources and benefit vs. total impact. Based on these criteria and their results, the authors conclude that the sustainability of land application of sludge is questionable and new energy/resource recovery technologies may be a more sustainable option.

\section{LCA for the generation of carbon dioxide in sludge treatment}

Hwang and Hanaki (2000) produced a very useful study with regard to emissions of carbon dioxide to the atmosphere. They have calculated carbon dioxide emission units (i.e. the amount of carbon dioxide emitted for treating a unit weight of sludge) for the most widely used sludge treatment processes. Their results are very useful in the sense that their calculated emission units can be used by different researchers in the field without the need for calculations. However, they fail to account for economies of scale (i.e. higher efficiency is achieved by larger process units) and for the influence of surrounding temperature (i.e. climate).

\section{LCA as an improvement tool in the operation of a membrane filtration process}

Meijers et al. (1998) performed an LCA to a membrane filtration process used in the production of potable water. The aim of this study was to generate information about the environmental consequences of this process and to provide recommendations for improving the environmental performance. In this study the operational stage was responsible for the majority of environmental burdens and the energy consumed in this stage to obtain optimal filtration pressures was of major importance. In addition to energy consumption the use of chemicals (sulphuric acid and carbon dioxide) for the cleaning-in-place of the membranes proved to cause significant environmental burdens. In view of these results the authors analysed different scenarios for environmental improvement and calculated an improvement factor for each scenario.

\section{LCA as a specific tool in the provision of materials for infrastructure}

Another LCA application in the water industry is presented by Dennison et al. (1999) in a study, which aimed to compare two different types of pipes used in the provision of potable water. The main purpose of the study was to quantify environmental impacts occurring throughout the life cycle of the different pipe materials and to integrate this information with cost, performance and legislative criteria to aid decision making regarding future pipe installations. The materials under analysis were ductile iron and medium-density polyethylene. For the ductile iron pipe it was found that the zinc protective coating contributed significantly to the environmental impacts of this pipe due to the high energy required by this process. For the medium- density polyethylene pipe, the production of polyethylene carried the highest environmental burdens. Most of the environmental burdens for both types of pipes could be traced to the constituent materials and only a few to the pipe manufacturing process. This highlights the fact that choosing materials with lower environmental burdens could dramatically improve the environmental performance of the entire system. This study falls short of recommending one type of pipe over another. However, it presents some interesting ideas with regard to the reuse and recovery of abandoned mains. One example of reuse is the laying of telecommunication cables in disused pipe networks.

Jeschar et al. (1995) published the results of an LCA study for pipes used for wastewater made of concrete (normal, fibrereinforced and steel-reinforced), vitrified clay, ductile iron, polyvinyl chloride and polyethylene (PE). They researched the acquisition of raw materials (including transport) from nature and the manufacture for a $1 \mathrm{~m}$ straight pipe, including the joint, for pipes with a diameter ranging from 100 to $500 \mathrm{~mm}$. They assumed the lifetimes of pipes to be identical. With regard to the energy consumption and the $\mathrm{CO}_{2}$ emissions due to the materials involved they published the figures presented in Table 3 . These results have been included in this review to illustrate a comparative, streamlined LCA with regard to one environmental impact category, namely global warming.

\begin{tabular}{|l|c|c|}
\hline \multicolumn{3}{|c|}{$\begin{array}{c}\text { TABLE 3 } \\
\text { Energy consumption and } \mathbf{C O}_{2} \text { emissions for } \\
\text { different piping materials }\end{array}$} \\
\hline Pipe material & $\begin{array}{c}\text { Energy consump- } \\
\text { tion (MJ/kg) }\end{array}$ & $\begin{array}{c}\mathbf{C O}_{2} \text { emissions } \\
\text { (kg CO } / \mathbf{k g})\end{array}$ \\
\hline Concrete & 1.24 & 0.148 \\
\hline Vitrified clay & 7.03 & 0.409 \\
\hline Ductile iron & 19.55 & 1.430 \\
\hline PVC & 68.30 & 4.860 \\
\hline
\end{tabular}

From the figures above it is evident that plastics have the highest energy consumption and $\mathrm{CO}_{2}$ emissions and concrete the least. The authors also took into account the energy consumption and emissions due to the seals involved and the different diameters of individual pipes which are linked with different amounts of material per metre of pipe. This study shows that for smaller OD pipes $(100$ and $150 \mathrm{~mm}$ ) the energy consumption for plastics and vitrified clay pipes is comparable. For larger OD pipes (300 and $500 \mathrm{~mm}$ ) the energy consumption for vitrified clay, concrete and fibre-reinforced concrete pipes is much lower than that for steel-reinforced concrete, ductile iron and plastics. The same trends are observed with regard to $\mathrm{CO}_{2}$ emissions. A shortcoming of this study is that lower OD concrete pipes have not been included, although they are produced and used.

In conclusion, the results published by Jeschar et al. (1995) point out that concrete (normal, fibre-reinforced and steelreinforced) and vitrified clay pipes have a better environmental performance than ductile iron and plastics. Another study undertaken at the Institute for Chemistry and the Environment (Forschungsinstitut für Chemie und Umwelt, 1996) linked to the Technical University Vienna reached similar conclusions with one major difference. Because this study took into account lifetimes of pipes, the environmental performance of ductile iron (as measured by energy consumption and consequent emissions during manufacture) is presented as much improved. None of these studies took into consideration toxicity issues due to the materials used. Of concern being the possibility of asbestos being released with the deterioration of the asbestos cement pipes. This aspect has not been included in the toxicity scores 
as presented and more research is needed. Also the roughness of the pipes and the resulting frictional pressure drop has not been considered.

\section{LCA and the anthropogenic water cycle}

The studies reviewed so far deal with specific aspects of water systems, either wastewater, sludge, etc. As a new trend two recent studies have attempted to incorporate more than one aspect and to approach water management holistically. Tarantini and Ferri (2001) have published the results from an LCA study that takes into consideration the production and distribution of drinking water, the collection of used water, its treatment and disposal for the city of Bologna, Italy. A similar study was performed by Rihon et al. (2002) for the hydrographic basin of La Vesdre, Belgium. As a main conclusion, both of these studies find that electricity consumption causes a large proportion of the environmental burdens of water systems. Further detailed comparisons of the results from these studies are not possible since they are differently structured and they use different methodologies. However, they also show that the results are dependent on local, individual conditions (e.g. the amount of pumping involved in the systems, the quality of incoming water or the effluent, etc.) and details cannot be generalised. These studies are similar in concept with the local research presented in this paper; however, neither of these two studies considers the effects of abstracting water from the environment.

\section{LCA as a strategic tool for the improvement/de- velopment of water services}

Sydney Water used LCA as a tool in reviewing its overall strategic planning (Lundie and Peters, 2000). The study covered the entire business and, as a first, a base case was produced. Scenario analyses were performed in order to examine the environmental consequences of additional demand management, energy efficiency, supply augmentation and effluent quality initiatives. Areas for improvement were detected, as were more desirable development scenarios for the future. For the base case four activities were singled out as major contributors (i.e. sewage plants, biosolids management, water reticulation and water filtration). Electricity consumption played the most important role for Sydney Water's global and regional impacts; however, the consumption of other materials should not be excluded. Construction materials were seen as relatively unimportant. Seven scenario analyses were performed and their results compared with the base case. From the normalised results three areas for improvement are evident. These are demand management, energy efficiency and energy generation.

\section{The South African experience in the use of LCA in the water industry with emphasis on the eThekwini case study}

To date there are three studies employing LCA in the water sector. The Water Research Commission (WRC) of South Africa has funded all three studies.

\section{The use of LCA for the production of potable water}

The first LCA study in the South African water industry (Friedrich, 2001) investigated the production of potable water by employing two different technologies and it was sponsored by the WRC (Project No 1077). The first technology is the 'con- ventional method' and is currently employed at Wiggins Waterworks, a waterworks of Umgeni Water situated in Durban and part of the eThekwini Municipality. The second method is based on the use of a South African membrane filtration technology and currently there are three pilot plants employing this technology in South Africa. The conclusion was that the main contribution towards the environmental burdens of potable water is the production of electricity. This conclusion is valid for both methods investigated, and as a result the recommendations focus on increasing the energy efficiency of waterworks in order to increase their overall environmental performance.

\section{LCA of water use in South Africa - The Rosslyn industrial area as a case study}

Landu and Brent (2006) have performed an LCA on the supply of water to the Rosslyn industrial area, north of Pretoria in the city of Tshwane. Their study included the extraction of water from the Vaal River, the purification and pumping at the Zuikerbosch Waterworks, the pumping at Palmiet and the storage and gravitation system in the Tshwane Municipality. In the life-cycle impact assessment they used a methodology developed by Brent (Brent, 2003; Brent, 2004 and Brent and Visser, 2005) for the different regions of South Africa which includes normalisation (see Table 1 for definition). The main conclusion of this study was that the 'actual extraction of the water from the ambient environment is in fact the most important consideration' (Landu and Brent, 2006) and therefore their main recommendation was to reduce water losses. The use of electricity and other energy inputs was seen as important but to a lesser extent.

\section{An LCA of the water value chain in the eThekwini Municipality}

The overall objective of this study was to generate information on the environmental life cycle of water (abstraction and treatment, distribution and collection and disposal (including recycling)) in an urban context and as a case study the eThekwini Municipality was used. One other aim of the study was to compare the environmental consequences for the provision of normal potable water vs. recycled water to industry in Durban. The results of this study can be used to evaluate any South African water and sanitation system that are based on similar processes to those investigated in this study.

The abstraction of water from the Inanda Dam was investigated by employing a simplified LCA. As such it looked at the major inputs and outputs from the construction and operation of the Inanda Dam and evaluated them with regard to their global warming potential. In addition to the classic LCA impact categories some aspects like change in land use for dams and social impacts were considered and the results are published in a technical report (Friedrich et al., 2006). The research on the treatment of water investigates the inputs and outputs from water treatment (Wiggins and Durban Heights Waterworks - Umgeni Water) plants in the Durban area. The different inputs and processes for these two plants have been quantified and environmental scores are calculated for each impact category. Details on these inputs and processes are presented in Friedrich et al. (2006). The distribution of treated water was researched for one particular distribution network, namely from Wiggins Waterworks to the southern Durban industrial area. This is the network, which includes the consumers (Mondi and Sapref), around the water recycling plant. The collection of used water is researched in a similar manner as the distribution. It consid- 


\begin{tabular}{|l|c|c|c|c|c|}
\hline \multicolumn{5}{|c|}{ Environmental LCA scores per ke water/wastewater 1 } \\
\hline Impact category & $\begin{array}{c}\text { Treatment of } \\
\text { raw water }\end{array}$ & $\begin{array}{c}\text { Distribution } \\
\text { of potable } \\
\text { water }\end{array}$ & $\begin{array}{c}\text { Collection of } \\
\text { waste- } \\
\text { water }\end{array}$ & $\begin{array}{c}\text { Treatment of } \\
\text { wastewater } \\
\text { (primary and } \\
\text { secondary) }\end{array}$ & $\begin{array}{c}\text { Recycling } \\
\text { plant } \\
\text { (tertiary) }\end{array}$ \\
\hline $\begin{array}{l}\text { Global warming potential } \\
\text { (kg CO, equivalents) }\end{array}$ & $1.32 \mathrm{E}-01$ & $1.95 \mathrm{E}-01$ & $1.78 \mathrm{E}-01$ & $4.15 \mathrm{E}-01$ & $1.01 \mathrm{E}-01$ \\
\hline $\begin{array}{l}\text { Ozone depletion potential } \\
\text { (kg CFC-11 equivalents) }\end{array}$ & $2.55 \mathrm{E}-09$ & $4.90 \mathrm{E}-9$ & $2.83 \mathrm{E}-9$ & $7.92 \mathrm{E}-09$ & $3.19 \mathrm{E}-09$ \\
\hline $\begin{array}{l}\text { Acidification potential } \\
\text { (kg SO, equivalents) }\end{array}$ & $8.29 \mathrm{E}-04$ & $11.10 \mathrm{E}-04$ & $11.50 \mathrm{E}-04$ & $23.70 \mathrm{E}-04$ & $5.68 \mathrm{E}-04$ \\
\hline $\begin{array}{l}\text { Eutrophication potential } \\
\text { (kg Phosphate equivalents) }\end{array}$ & $5.54 \mathrm{E}-05$ & $8.44 \mathrm{E}-5$ & $8.90 \mathrm{E}-5$ & $1.53 \mathrm{E}-04$ & $3.51 \mathrm{E}-05$ \\
\hline $\begin{array}{l}\text { Photo-oxidant formation Potential } \\
\text { (kg Ethene equivalents) }\end{array}$ & $1.28 \mathrm{E}-05$ & $2.31 \mathrm{E}-5$ & $1.12 \mathrm{E}-5$ & $3.05 \mathrm{E}-05$ & $1.05 \mathrm{E}-05$ \\
\hline $\begin{array}{l}\text { Aquatic ecotoxicity potential } \\
\text { (kg DCB* equivalents) }\end{array}$ & $1.79 \mathrm{E}-03$ & $2.60 \mathrm{E}-03$ & $2.40 \mathrm{E}-03$ & $6.57 \mathrm{E}-03$ & $1.00 \mathrm{E}-03$ \\
\hline $\begin{array}{l}\text { Terrestrial ecotoxicity Potential } \\
\text { (kg DCB* equivalents) }\end{array}$ & $1.83 \mathrm{E}-01$ & $3.53 \mathrm{E}-01$ & $2.02 \mathrm{E}-01$ & $5.64 \mathrm{E}-01$ & $1.25 \mathrm{E}-01$ \\
\hline $\begin{array}{l}\text { Human toxicity potential } \\
\text { (kg DCB* equivalents) }\end{array}$ & $2.94 \mathrm{E}-03$ & $7.20 \mathrm{E}-03$ & $3.00 \mathrm{E}-03$ & $8.48 \mathrm{E}-03$ & $1.77 \mathrm{E}-03$ \\
\hline
\end{tabular}

${ }^{I}$ Note: The functional units $(1 \mathrm{kl})$ are not equivalent since the quality of the water/wastewater is different and cannot be added directly *All toxicity scores are expressed in $\operatorname{kg} D C B(1,4$ dichlorobenzene) equivalents

ers the parallel sewerage system of the southern Durban area used for distribution. In the distribution and collection the piping networks as well as the energy inputs due to pumping have been included. The treatment of wastewater and the recycling of water were investigated by using as case studies the Southern Wastewater Treatment Plant and the Durban Water Recycling Plant. The treatment of wastewater includes primary treatment (de-gritting and primary settling) and secondary treatment (activated sludge and clarifiers). The recycling plant (tertiary treatment of wastewater) employed the following process units: lamellae settlers, dual media filters, ozonators, granular activated carbon filters and chlorinators. The chemicals used in tertiary treatment were also included. Environmental scores were calculated and an improvement assessment was performed while considering the existing scenario. The research into the disposal to sea of effluents investigated the toxicity of these effluents on the marine ecosystem and on human health. These results are presented in Friedrich et al. (2006).

LCA scores have been calculated for an array of environmental impacts for the treatment and distribution of potable water and for the collection and treatment (including recycling) of wastewater. These scores have been summarised in Table 4.

From Table 4 it can be seen that per $\mathrm{k} \ell$ of water/wastewater the stage with the highest LCA scores throughout is the treatment of wastewater. This includes primary and secondary treatment. The distribution of potable water has the second highest LCA scores and the collection of wastewater the third highest scores. The water recycling plant has the lowest overall LCA scores (with the exception of the ozone depletion potential).

From these scores it is obvious that, except ozone depletion, the replacement of $1 \mathrm{k} \ell$ of treated water with $1 \mathrm{k} \ell$ recycled water is the environmentally better option. If taking into account not only the treatment of raw water but also the distribution of this water then, even for ozone depletion, recycling is more environmentally friendly. Thus one of the main questions of the research project was answered and it makes a strong case for the promotion of water recycling for supplying industries situated close to wastewater treatment plants. This conclusion is also

\begin{tabular}{|l|c|c|}
\hline \multicolumn{3}{|c|}{ TABLE 5 } \\
\hline Losses in the eThekwini water cycle \\
\hline Process & $\begin{array}{c}\text { Amount } \\
\text { (ke) }\end{array}$ & $\begin{array}{c}\text { Loss } \\
\text { (\%) }\end{array}$ \\
\hline Abstraction of water - Inanda Dam & 1 & 0 \\
\hline $\begin{array}{l}\text { Purification of water - Wiggins and } \\
\text { Durban Heights Waterworks }\end{array}$ & 0.97 & 1.5 and 3\% \\
\hline Distribution of water- municipality & 0.68 & $30 \%$ \\
\hline Use of water - domestic consumers & 0.41 & $40 \%$ \\
\hline Treatment of water & 0.41 & $0 \%$ \\
\hline Disposal to sea & 0.41 & $0 \%$ \\
\hline
\end{tabular}

supported by the results of Landu and Brent (2006) where the extraction of water from the environment is seen as the most important impact in the supply of water. Recycling of water will obviously reduce the need for extraction, treatment, distribution and collection.

Table 4 does not take into account the losses in the water cycle and therefore these have to be included. Table 5 presents these figures. The losses for Wiggins and Durban Heights Water were obtained from Umgeni Water personnel (Thompson, 2005). The loss for the distribution was obtained from the eThekwini Municipality and that for wastewater from the eThekwini Water Services personnel (Davies, 2005 and Howarth, 2005).

From Table 5 the overall loss from the abstraction to the disposal of water is calculated to be $59 \%$. This does not take into account the water recycled and it assumes that the wastewater loss due to leakage is zero. This total loss should be seen as an economical/efficiency loss for the provision of water which has environmental consequences and not as a total environmental loss of water. The water making up the losses is returned to the environment just not inside the water provision cycle. For example, in the $40 \%$ loss due to usage by domestic consumers, watering of gardens is included. Taking into account the losses presented in Table 5 and the environmental scores as shown in Table 4 new scores are calculated for $1 \mathrm{k} \ell$ of water delivered to the consumers. To deliver this amount $(1 \mathrm{k} \ell)$ to consumers, 1.47 


\begin{tabular}{|c|c|c|c|c|c|}
\hline \multicolumn{6}{|c|}{$\begin{array}{r}\text { TABLE } 6 \\
\text { Environmental LCA scores for the provision } 0\end{array}$} \\
\hline Impact category & $\begin{array}{c}\begin{array}{c}\text { Abstraction } \\
\text { of raw water } \\
(1.47 \mathrm{k \ell})\end{array} \\
\end{array}$ & $\begin{array}{c}\text { Treatment of raw } \\
\text { water } \\
(1.47 \mathrm{k \ell})\end{array}$ & $\begin{array}{c}\begin{array}{c}\text { Distribution } \\
\text { of potable } \\
\text { water }\end{array} \\
(1.43 \mathrm{k \ell})\end{array}$ & $\begin{array}{c}\begin{array}{c}\text { Collection of } \\
\text { waste- } \\
\text { water }\end{array} \\
(0.60 \mathrm{k \ell})\end{array}$ & $\begin{array}{c}\text { Treatment of } \\
\text { wastewater } \\
\text { (primary and } \\
\text { secondary) } \\
(0.60 \mathrm{kl})\end{array}$ \\
\hline $\begin{array}{l}\text { Global warming potential } \\
\text { (kg CO}, \text { equivalents) }\end{array}$ & $\begin{array}{c}0.88 \mathrm{E}-01 \\
(9.51 \%)\end{array}$ & $\begin{array}{l}1.94 \mathrm{E}-01 \\
(20.97 \%)\end{array}$ & $\begin{array}{l}2.87 \mathrm{E}-01 \\
(\mathbf{3 1 . 0 3} \%)\end{array}$ & $\begin{array}{l}1.07 \mathrm{E}-01 \\
(11.57 \%)\end{array}$ & $\begin{array}{l}2.49 \mathrm{E}-01 \\
(26.92 \%)\end{array}$ \\
\hline $\begin{array}{l}\text { Ozone depletion potential } \\
\text { (kg CFC-11 equivalents) }\end{array}$ & $\mathrm{N} / \mathrm{A}$ & $\begin{array}{l}3.75 \mathrm{E}-09 \\
(21.55 \%)\end{array}$ & $\begin{array}{c}7.20 \mathrm{E}-9 \\
(\mathbf{4 1 . 3 8} \%)\end{array}$ & $\begin{array}{l}1.70 \mathrm{E}-9 \\
(9.77 \%)\end{array}$ & $\begin{array}{l}4.75 \mathrm{E}-09 \\
(27.30 \%)\end{array}$ \\
\hline $\begin{array}{l}\text { Acidification potential } \\
\text { (kg SO, equivalents) }\end{array}$ & $\mathrm{N} / \mathrm{A}$ & $\begin{array}{l}12.19 \mathrm{E}-04 \\
(24.56 \%)\end{array}$ & $\begin{array}{l}16.32 \mathrm{E}-04 \\
(32.88 \%)\end{array}$ & $\begin{array}{l}6.90 \mathrm{E}-04 \\
(13.90 \%)\end{array}$ & $\begin{array}{l}14.22 \mathrm{E}-04 \\
(28.65 \%)\end{array}$ \\
\hline $\begin{array}{l}\text { Eutrophication potential } \\
\text { (kg Phosphate equivalents) }\end{array}$ & $\mathrm{N} / \mathrm{A}$ & $\begin{array}{l}8.12 \mathrm{E}-05 \\
(23.15 \%)\end{array}$ & $\begin{array}{l}12.41 \mathrm{E}-5 \\
(35.39 \%)\end{array}$ & $\begin{array}{c}5.34 \mathrm{E}-5 \\
(15.23 \%)\end{array}$ & $\begin{array}{l}0.92 \mathrm{E}-04 \\
(26.23 \%)\end{array}$ \\
\hline $\begin{array}{l}\text { Photo-oxidant formation potential } \\
\text { (kg ethene equivalents) }\end{array}$ & N/A & $\begin{array}{l}1.88 \mathrm{E}-05 \\
(24.17 \%)\end{array}$ & $\begin{array}{c}3.40 \mathrm{E}-5 \\
(43.70 \%)\end{array}$ & $\begin{array}{l}0.67 \mathrm{E}-5 \\
(8.61 \%)\end{array}$ & $\begin{array}{l}1.83 \mathrm{E}-05 \\
(23.52 \%)\end{array}$ \\
\hline $\begin{array}{l}\text { Aquatic ecotoxicity potential } \\
\text { (kg DCB* equivalents) }\end{array}$ & N/A & $\begin{array}{l}2.63 \mathrm{E}-03 \\
(22.23 \%)\end{array}$ & $\begin{array}{l}3.82 \mathrm{E}-03 \\
(32.29 \%)\end{array}$ & $\begin{array}{l}1.44 \mathrm{E}-03 \\
(12.17 \%)\end{array}$ & $\begin{array}{l}3.94 \mathrm{E}-03 \\
(\mathbf{3 3 . 3 0} \%)\end{array}$ \\
\hline $\begin{array}{l}\text { Terrestrial ecotoxicity Potential } \\
\text { (kg DCB* equivalents) }\end{array}$ & $\mathrm{N} / \mathrm{A}$ & $\begin{array}{l}2.69 \mathrm{E}-01 \\
(21.57 \%)\end{array}$ & $\begin{array}{c}5.19 \mathrm{E}-01 \\
(\mathbf{4 1 . 6 2} \%)\end{array}$ & $\begin{array}{l}1.21 \mathrm{E}-01 \\
(9.70 \%)\end{array}$ & $\begin{array}{l}3.38 \mathrm{E}-01 \\
(27.10 \%)\end{array}$ \\
\hline $\begin{array}{l}\text { Human toxicity potential } \\
\text { (kg DCB* equivalents) }\end{array}$ & $\mathrm{N} / \mathrm{A}$ & $\begin{array}{l}4.32 \mathrm{E}-03 \\
(19.83 \%)\end{array}$ & $\begin{array}{l}10.58 \mathrm{E}-03 \\
\mathbf{( 4 8 . 5 5 \% )}\end{array}$ & $\begin{array}{l}1.80 \mathrm{E}-03 \\
(8.26 \%)\end{array}$ & $\begin{array}{l}5.09 \mathrm{E}-03 \\
(23.36 \%)\end{array}$ \\
\hline
\end{tabular}

${ }^{*}$ All toxicity scores are expressed in $\mathrm{kg} D C B(1,4$ dichlorobenzene) equivalents

$\mathrm{k} \ell$ needs to be extracted from Inanda Dam and to be treated at Durban Heights and Wiggins Waterworks. At consumer level from the $1 \mathrm{k} \ell$ delivered only $0.6 \mathrm{k} \ell$ wastewater is collected ( $40 \%$ loss) and this is the amount which enters the wastewater treatment plant and the recycling plant. Table 6 presents the environmental scores recalculated for these amounts.

When investigating these LCA scores, the process which carries the highest environmental burden is the use of electricity for pumping. It dominates the scores for all the environmental impact categories for all the stages presented in Table 4. More details on individual stages are presented in a technical report (Friedrich et al., 2006). This is a strong argument for the use of an electricity index as a measure of environmental performance for urban water systems.

\section{Advantages and limitations in using electricity consumption as an environmental indicator for the South African water industry}

From the previous section it was concluded that electricity plays an important role for the environmental performance of water systems. Electricity is the highest contributor to all of the environmental LCA scores for the production and distribution of potable water as well as for the collection of wastewater. Therefore, in this section it is proposed to use an electricity index as a measure of environmental performance for urban water systems in South Africa. The amount of energy expressed as $\mathrm{kWh} / \mathrm{k} \ell$ of water (potable or wastewater) is enough to simplistically judge the overall environmental performance of existing processes involved in the treatment of water. It is also a relatively easy index to use from the point of view of the technical staff involved in operating water plants and pumping stations and which usually are not familiar with global warming and $\mathrm{CO}_{2}$ equivalents. The use of an electricity index would be a good measure, as long as the underlying data (i.e. electricity consumption) can be measured reliably and assigned to different operations or processes. For some municipalities this is not always the case. The other instance where this index is inappropriate is when the topogra- phy of a municipality allows for water systems where pumping is not required.

\section{General shortcomings of LCA tools and associ- ated implications}

There are two types of limitations and problems facing the South African LCA practitioner and these are reflected in the use of this tool in the water sector. The first set of problems shows the limitations and problems related to the LCA tool and methodological framework in general, and the second set of problems is specific for the South African setting. The main areas where shortcomings were noted for LCAs have been related to data gaps, data quality and value-choices in the methodology. From the literature (Owens, 1996; Owens, 1999 and Friedrich, 2001) on the general shortcomings of LCAs the following main points have been summarised:

- Energy inputs are included in most cases without major gaps

- Other raw materials are included but with severe data gaps

- Water is in most cases not included

- Land use, habitat alterations and impacts on biodiversity are in most cases not included. These categories will continue to pose a methodological problem, since there is no agreement on how to consider them in an inventory analysis.

- Toxicological impacts on humans and on ecosystems are often included, but with severe data gaps. It is estimated that these impacts will never be fully described without data gaps, because of the sheer number of chemicals used in society and the lack of knowledge on the behaviour of these chemicals.

- Impacts like global warming, ozone depletion, acidification, eutrofication and photo-oxidant formation are fairly well covered, however, there are shortcomings. Most notably, data on eutrophication of aquatic systems is usually incomplete (due to insufficient data for water emissions), and data for organic compounds contributing towards photo-oxidant formation is expressed as a general parameter (e.g. particulate emission) making differentiation impossible. 
These limitations are also reflected in the case studies reviewed in this paper. For example, the use of water for the production of the inputs (e.g. chemicals) in the treatment of water has not been included in all the studies reviewed. The same is valid for impact categories like land use, habitat alteration or the impacts on biodiversity. The limitations listed above have the potential to influence the interpretation of the environmental scores as presented in Table 4 and Table 6 by highlighting the uncertainties in the LCA methodology used to calculate these scores. In addition, it is important to emphasise that the LCA scores presented in this paper and in general all scores from LCA studies reflect the potential, calculated environmental impacts and not the actual impacts. To address some of these problems a series of sensitivity analyses were performed to determine the sensitivity of the scores to different changes in the input data. From these analyses it was concluded that the scores presented in Table 4 and Table 6 were not sensitive to large changes to some of the inputs, like chemicals, but were very sensitive to small changes of inputs like energy. This reinforced the importance of the role of energy in water systems. In this case the potential bias towards energy inputs, because data for energy might be more complete, as compared to other inputs is considered small. An argument to support this point is the fact that other energy intensive inputs (e.g. chlorine) do not feature as high contributors towards the final environmental scores.

The limitations of LCAs in South Africa, including the water sector, are related to data availability and quality and to the omission of local environmental issues in the assessment step of the methodology. With regard to data availability there is a general reluctance by companies to provide LCA data. However, with more local studies being published, some of the data gaps are being filled. Another major limitation of LCAs is the relevance to this country of the LCA methodology developed overseas. In addition to the environmental impact categories listed in Table 1, section 3, South Africa is facing some important environmental issues like water scarcity, salinisation and soil erosion, which were not included in the LCA methodology developed overseas. There is a need to adapt the methodology to include these local environmental priorities and some steps, most notably with regard to salinisation, have been undertaken in this direction (Friedrich et al., 2006). Furthermore, to make the whole life cycle impact assessment phase of the methodology more relevant to South Africa, regional and local characterisation factors should be developed for each of the impact assessment categories where locality is relevant (acidification, eutrophication, smog formation and toxicity impacts).

\section{Conclusion and recommendation}

In conclusion, LCA proves to be a very versatile tool for use in the water industry. It can address different problems and answer different questions as shown in the review part of this paper. A common theme emerging from the international LCA research in the water industry is that energy consumption in the treatment of water and wastewater is a critical factor for the overall environmental performance of water systems. This conclusion is also supported by the local LCA case studies. The use of LCA in the local water industry has shown that, with regard to the supply of water, the abstraction of water from the environment (in a country were it is a limited resource) and the use of energy for treating and pumping water have the highest environmental impacts. Therefore, the main recommendation emerging from these results is that improving energy efficiency of water systems will increase their overall environmental performance. The first step is to address leakage in the supply of water in urban areas and to reduce water losses as much as possible. This will improve the overall environmental performance of urban water systems, firstly by conserving a valuable resource and secondly by preventing the pollution and emissions associated with the electricity used in the production of potable water, which is then wasted. The recycling of water in situations where consumers of recycled water are close to water treatment plants and recycling plants should be encouraged. If water has been treated to a quality, which is acceptable to be discharged to a river, it could with a little effort replace extracted river water. However, in situations where major pumping is required, this has to be investigated, since increased use of energy may offset the environmental benefits from recycling.

For the treatment processes of water and wastewater the energy inputs (i.e. electricity) carry the highest environmental burdens and there is a strong correlation between the environmental scores for an array of impacts and energy consumption. For that reason it is proposed that, in South Africa, electricity consumption should be used as a crude environmental indicator for the performance of urban water systems. An electricity index (e.g. $\mathrm{kWh} / \mathrm{k} \ell)$ is proposed to be applied to the treatment processes and pumping of water and wastewater. A compilation of such indexes for South African urban areas would assist in benchmarking and comparing environmental performances. It will also highlight areas for improvement.

Another set of recommendations is aimed at assisting to overcome the limitations in the use of the LCA methodology in general and in particular the applications in the South African water sector. With regard to the limitations imposed by data availability, data quality and system definition issues the use of sensitivity and uncertainty analyses are recommended. To make the life-cycle impact assessment more relevant to local conditions the methodology for this stage should be further developed in this country to incorporate impacts, like water scarcity and soil erosion. It is also recommended that the proposed methodology on how to include salinisation in LCAs should be consolidated and publicised to a wider audience. In addition, regional and local characterisation factors should be developed for each of the impact assessment categories where locality is relevant.

\section{Acknowledgements}

The authors would like to thank the Water Research Commission (WRC) of South Africa for funding the research on the eThekwini case study. The help of all the personnel from the eThekwini Municipality and Umgeni Water is also gratefully acknowledged.

\section{References}

BRIDLE T and SKRYPSKI-MANTELE S (2000) Assessment of sludge reuse options: A life cycle approach. Water Sci. Technol. 41 (8) 131135

DANISH EPA (2002) Wastewater Treatment Plant Reduces Environmental Gains. Report by the Industry Division of the Danish EPA and published electronically at: http://glwww.mst.dk/publica projects/2001/87-7944-240-4.htm (Accessed in Jan 2007).

DAVIES P (2005) Personal communication. eThekwini Municipality Water Services, South Africa.

DENNISON FJ, AZAPAGIC A, CLIFFT R and COLBOURNE JS (1998) Assessing management options for wastewater treatment works in the context of life cycle assessment. Water Sci. and Technol. 38 (11) 23-30.

DENNISON FJ, AZAPAGIC A, CLIFFT R and COLBOURNE JS (1999) Life cycle assessment: Comparing strategic options for the 
mains infrastructure - Part I. Water Sci. Technol. 39 (10-11) 315319.

EMMERSON RHC, MORSE GK, LESTER JN and EDGE DR (1995) The life-cycle analysis of small scale sewage-treatment processes. J. CIWEM. $9317-325$

FORSCHUNGSINSTITUT FÜR CHEMIE UND UMWELT (FICU) a the Technical University Vienna (ed.) (1996) Ökologischer Vergleich von Rohren aus verschiedenen Werkstoffen - Ergebnisbericht als Grundlage für ein ökologlisches Beschaffungshandbuch. Vienna, Austria.

FRIEDRICH E (2001) The Use of Environmental Life Cycle Assessment for the Production of Potable Water. M.Sc. Eng. Thesis, Pollution Research Group, University of Natal, Durban, South Africa

FRIEDRICH E, BUCKLEY CA, PILLAY S and LESKE A (2006) A Life Cycle Assessment of a Secondary Water Supply. WRC Report No. 1252/1/06, Water Research Commission, Pretoria, South Africa HOWARTH C (2005) Personal communication. eThekwini Municipality Water Services

HWANG Y and HANAKI K (2000) The generation of $\mathrm{CO}_{2}$ in sewage sludge treatment systems: life cycle assessment. Water Sci. and Technol. 14 (8) 107-113.

ISO 14040, (1997) Environmental Management-Life Cycle Assessment - Principles and Framework. South African Bureau of Standards, Pretoria, South Africa.

JENSEN AA, ELKINGTON J., CHRISTIANSEN K, HOFFMANN L, MOLLER BT, SCHMIDT A and VAN DIJK F (1997) Life Cycle Assessment (LCA) - A Guide to Approaches, Experiences and Information Sources. Report to the European Environmental Agency, Copenhagen, Denmark.

JESCHAR R, SPECHT E and STEINBRUECK A (1995) Energieverbrauch und $\mathrm{CO}_{2}$-Emission bei der Herstellung und Entsorgung von Abwasserrohren aus Verschiedenen Werkstoffen. Korrespondenz Abwasser 42 (4) 537-549.
LANDU L and BRENT AC (2006) Environmental life cycle assessment of water supply in South Africa: The Rosslyn industrial area as a case study. Water SA 32 (2) 249-256.

LUNDIE S and PETERS G (2002) Sydney Water - WaterPlan 21 Life Cycle Assessment. Paper for the $3^{\text {rd }}$ Australian LCA Conference, Gold Coast, 17-19 July 2002. http://lca-conf.alcas.asn.au/Papers/ Lundie Peters Beavis WP21.pdf (Accessed in June 2006).

MEIJERS K, VERBERNE AJP and KOREMAN EA (1998) Levenscyclusanalyse van membraanfiltraatie. $\mathrm{H}_{2} \mathrm{O} 21$ 33-36

OWENS WJ (1997) Life cycle assessment - Constraints on moving from inventory to impact assessment. J. Ind. Ecol. 1 (1) 37-49.

OWENS WJ (1999) Why Life Cycle Impact Assessment is Now Described as an Indicator System. Int. J. LCA. 4 (2) 81-86.

RALUY GR, SERRA L and UCHE J (2005) Life Cycle Assessment of Water Production Technologies - Part 1: Life Cycle Assessment of Different Commercial Desalination Technologies. Int. J. LCA. 10 (4) 285-293

RIHON AC, LASSAUX S and GERMAIN A (2002) Application of the LCA methodology to water management from the pumping station to the wastewater treatment plant. Proc. 10 $0^{\text {th }}$ SETAC LCA Case Studies Symposium, 2-3 Dec 2002. Barcelona, Spain.

STROKES J and HORVATH A (2006) Life Cycle Energy Assessment of Alternative Water Supply. Int. J. LCA. 11 (5) 335-343.

TARANTINI M and FERRI F (2001) LCA of Drinking and Wastewater Treatment Systems of Bologna City: Final Results. Proc. $4^{\text {th }}$ IRCEW Conference, 27-30 Aug 2001. Fortalenza, Brazil.

THOMPSON P (2005) Personal communication. Umgeni Water, South Africa.

VIDAL N, POCH M, MARTI E and RODRIGUEZ-RODA I (2002) Evaluation of the Environmental Implications to Include Structural Changes in a Wastewater Treatment Plant. J. Chem. Tech. Biotech. 77 1206-1211.

ZHANG Z and WILSON F (2000) Life Cycle Assessment of a Sewage Treatment Plant in South-East Asia. J. CIWEM. 14 51-56. 
Available on website http://www.wrc.org.za ISSN 0378-4738 = Water SA Vol. 33 No. 4 July 2007 ISSN 1816-7950 = Water SA (on-line) 